\title{
Domestic Water Utilization and Its Determinants in the Rural Areas of Oyo State, Nigeria Using Multivariate Analysis
}

\author{
T. O. Ogunbode ${ }^{1^{*}}$ and I. P. Ifabiyi ${ }^{1}$ \\ ${ }^{1}$ Department of Geography and Environmental Management, University of Ilorin, Ilorin, Nigeria.
}

Authors' contributions

This work was carried out in collaboration between both authors. Both authors read and approved the final manuscript.

Article Information

DOI: $10.9734 /$ ARJASS/2017/34096

Editor(s):

(1) Raffaela Giovagnoli, Pontifical Lateran University, Piazza San Giovanni in Laterano 4, Rome, Italy.

Reviewers:

(1) S. O. Adesogan, University of Ibadan, Nigeria.

(2) Kadiri Umar Afegbua, Centre for Geodesy and Geodynamics, Nigeria. Complete Peer review History: http://www.sciencedomain.org/review-history/19513

Original Research Article

Received $13^{\text {th }}$ May 2017

Accepted $31^{\text {st }}$ May 2017

Published $13^{\text {th }}$ June 2017

\begin{abstract}
Investigation into water utilization and its determinants in the rural areas is salient to a resultoriented management of this resource. Thus, a research was conducted to assess the pattern of domestic water uses and its determinant in the rural areas of Oyo State, Nigeria. A multistage sampling technique was applied to select 124 villages from 25 out of the 33 LGAs in Oyo State, Nigeria with 5 villages from each. Ten structured questionnaire were administered in each of the selected villages, giving a total of 1240 across the study area to generate data. The study revealed that water consumtion per head in the study area ranges between 15 litres/day in Shaki East and 31.7 litres/day in Oyo East LGA and that the dominant water consumption is absolutely domestic indicating that the study area is non-industrialized. Also, multivariate analysis conducted showed that 11 factors were determinants of domestic water consumption in the study area. These are water storage, cost of water, household size, water use for bathing, availability of alternative sources, location, reliability and accessibility of the source, distance, age of the respondent and gender composition. Multiple regression analysis of $R^{2}=35.0$ for Oyo State indicated that each LGA should be treated individually when seeking solutions to water-related problems in the State. The study recommended detail survey on what determines water use in each LGA for a result-oriented water management. Effort is required of relevant agencies to embark on infrastructural and agricultural development in the area to boost water use.
\end{abstract}


Keywords: Water utilization determinants; rural areas; Oyo State; domestic water; multivariate analysis.

\section{INTRODUCTION}

Human survival and well-being in space and time is partly dependent on the access to and the utilization of potable water. Water is required in homes for different purposes including bathing, drinking, cooking, laundry and cleaning among others. Thus, the United Nations had recommended that an adult man should have access to an average of 115 litres per day [1]. According to [2], water use patterns are highly complex processes that are influenced by many factors including seasonal variability and water availability. In buttressing this view, [3] and [4] observed that a clear understanding of water use patterns and the factors that affect water consumption is critical to the effective management of water supply and effective design of water-related public policies. The findings of several scholars on domestic water utilization have, however, established these views because different factors determine domestic water utilization in space and time [4]. For instance, [5] found that water consumption significantly correlated with household size and age of household head. Similarly, [6] noted that water use for bathing and dish washing, age range of water suppliers, quantity of water supplied and household size influence the utilisation of water in Iwo, Nigeria. According to World Bank records, half of the world's population lives in rural regions, $76.5 \%$ of which lives in developing countries [7], the region that have been found to more prone to the problem associated with water scarcity and consumption of water from unreliable sources (see also [8]).

However, domestic water use in rural areas has been discovered to be dominantly domestic. [9], in his study observed that domestic water consumption varies according to living standards of the consumers in urban and rural areas. Thus, [5] and [3] remarked that rural households use water for both indoor and outdoor purposes. [5], [3] and [10] noted that indoor water use includes consumption for drinking, hygiene (bathing, laundry and cleaning) while outdoor activities include car washing, livestock water, garden and small-scale greenhouse watering and yard cleaning. These views revealed that water use in the rural areas is mostly limited to domestic and that the uses of water for other purposes like industrial and aesthetic are less important. This study has been conducted to assess water utilization and its determining factors in the rural areas of Oyo State. Specific objectives are to: (i) determine the pattern of domestic water use per head in the rural areas of Oyo State; (ii) assess varying uses of water in the study area; (iii) determine the factors that influence domestic water use in the study area; and (iv) evaluate the relationship between household water demand and water use components in Oyo State.

\section{STUDY AREA}

Oyo State is located between $800 \mathrm{~N}$ and $400 \mathrm{E}$. The State covers approximately an area of $28,454 \mathrm{~km}^{2}$ and is ranked fourteenth by size in the country. The landscape consists of old hard rocks and dome shaped hills, which rise gently from about 500 metres in the southern part and reaching a height of about 1,219 metres above sea level in the northern part. Some major rivers such as Ogun, Ofiki, Otin, Oba, Oyan, Sasa, Oni, Erinle and Osun rivers take their sources from this highland [11]. The climate of Oyo State exhibits the tropical climate of averagely high temperatures, high relative humidity and generally low rainfall maxima regimes during the rainfall period. The dry season lasts from November to March while the wet season starts from March and ends in October. Rainfall amount varies from an average of $1200 \mathrm{~mm}$ around Igbeti in the northern part of the State and 1800 $\mathrm{mm}$ in Igbo-Ora and Ibarapa zone in the southern part. According to [12], the rainfall pattern in the southwest is mostly influenced by the sea surface temperature of the Gulf of Guinea. However, wet season is usually characterised with large surface runoff with high humidity especially in the southern part of the State.

Average daily temperature ranges between $25^{\circ} \mathrm{C}$ (77.0\%) and $35^{\circ} \mathrm{C}$ (95.0\%) almost throughout the year. The mean temperatures are highest at the end of harmattan (averaging ${ }^{\circ} 8^{\circ} \mathrm{C}$ ). It was even on the record that during the rainfall months, average temperatures are between $24^{\circ} \mathrm{C}$ and $25^{\circ} \mathrm{C}$ while annual range of temperature is about $6^{\circ} \mathrm{C}$. Rainfall figures over the state vary from an average of $1200 \mathrm{~mm}$ at the onset of heavy rains to $1800 \mathrm{~mm}$ at its peak in the southern part of the state to an average of between $800 \mathrm{~mm}$ and $1500 \mathrm{~mm}$ at the northern part of the state. Thus, Oyo State is endowed with a vast of water surplus on annual basis in form of both surface and subsurface sources [11]. 
According to [13] rural area is defined with the use of criteria such as low population density, predominance of agricultural related livelihood and poor infrastructural services. [14] supporting the above rural description argued that the features that characterized rural areas include specific open landscape, a relatively low population, dominance of primary activities, proximity to nature, dispersed settlements and extensive use of land. [15] also in supporting the agrarian characteristics of rural areas opined that agriculture is placed at the centre of economic life of rural communities and it is around this that other enterprises revolve. From the ongoing, it needs to be stated that Oyo State, even though with many towns including Ibadan (the State capital), Ogbomoso, Oyo, Iseyin, and so on, is characterised by rural settlements to the extent that most citizens of the State maintain dual citizenship claiming one major town and another rural community often belonging to family lineage.

\section{METHODS OF DATA COLLECTION AND ANALYSIS}

The study covers 124 rural settlements with 5 each randomly selected from 25out of the 33 local government areas in the State. The villages selected for the purpose of this investigation are shown in Appendix I.

Multistage random sampling method was used to arrive at the sample selected for the investigation. Thus, 25 rural local government areas were selected within Oyo State from which 5 rural settlements were selected. In furtherance, 10 households were randomly selected from each of the villages. Thus a total of one hundred and twenty five villages were selected for investigation in the study area. On the whole, 10 questionnaire were administered across the 10 households in each of the villages. Thus, a total of 1,250 copies of questionnaire were administered in the study area.

The data was sujected to both descriptive and inferential statistical analysis. Average domestic water utilisation per head was determined from the mean values of the households water use in each of the villages investigated. Also, the data was further subjected to factor analysis to arrive at what factors determine domestic water use in the study area.The application of multivariate analysis is not new in domestic water studies. For instance, [16], and [6] applied factor analysis to arrive at the dominant domestic water use components and also stepwise regression analysis to arrive at an all-inclusive predictive model in their study area.

\section{RESULTS AND DISCUSSION}

\subsection{Water Utilisation in the Study Area}

The summarised average water use per head through each of the LGA investigated is presented in Table 1 and depicted in Fig. 2. The result revealed that water consumtion per head in the study area ranges between 15 litres/day in Shaki East and 31.7 litres/day in Oyo East LGA. This wide variation is as a result of presence of some cottage industries such as gari and palm oil processing factories in some of the villages investigated. Also, evidences of some outdoor activities in some of these villages such as livestock keeping and garden watering partly explain disparities in water consumption in the study area.

The results showed that the dominant use of water in the rural areas of Oyo State as revealed in Table 2 is domestic. The uses include drinking (100 percent), cooking (100 percent), bathing (100 percent), and cloth/dish washing (100 percent). However, the use of water for sanitary purpose (2.60 percent), car washing (19.68 percent) and others (11.86 percent) were not significant due to their poverty level and access to water $([17,18,19])$. The proportion of car washing was dominated by washing of motorcycles and few vehicles. In addition, the category of other uses of water probably include religious use (like ablution and miracle purposes), livestock feeding among others. The observation in this study implies that the study area is an agrarian economy as equally noted by [20] and [21].

The results showed that average daily water use per household in the rural areas (Appendix I) of Oyo State ranges between 7.7 litres/day in OkeAmu (Iseyin LGA) and 46.45 litres/day Apata (Itesiwaju LGA). The study revealed that OkeAmu community has an average of 5 to 10 members per household while the size ranges from 11 to 15 in Apata community (Iseyin LGA). Apart from these, other few communities that use up to an average of $40 \mathrm{Lpd}$ include Geesi (Irepo LGA), 40.3 Lpd, Apenpe (41.3 Lpd) and Apata (46.45 Lpd), both in Iseyin LGA, and Aba-Loya (43.66 Lpd) and Tokun-Idode (40.45), both in Oyo East LGA. The daily demand of water in communities like Oke-Amu (Itesiwaju LGA), Olose (Egbeda) and Oju-Oro (Akinyele) were 
among the least as they respectively use 9.65Lpd, $8.5 \mathrm{Lpd}$ and $12 \mathrm{Lpd}$. Thus, it can be inferred that Oyo State fell short of the international recommended daily water use of $115 \mathrm{Lpd}$ [1] as a result of low daily water use per head. The low use of water is attributed to lack of basic amenities and poor economy, being an agrarian type. The findings here corroborated the works of [22] and [23].

\subsection{Domestic Water Demand Components in the Rural Areas of Oyo State}

Factor analysis was applied to determine variables that explain domestic water use in the rural areas of Oyo State. The data was initially subjected to Kaiser-Meyer-Olkin (KMO) measure of sampling adequacy and Barttlets Test of Sphericity. The results as presented in Table 3 showed that the $\mathrm{KMO}$ is 0.678 while Bartlett's Test is 0.000 , indicating that the dataset is adequate for factor analysis.

Out of the 41 water demand variables investigated as shown in Appendix II, eleven (11) variables were extracted by factor analysis. The 11 variables extracted explain 62.47 percent of the variations in rural water supply in Oyo state.

As indicated in Table 4, the type of storage facility with eigen-value of 4.33 contributed highest percentage of variance of 10.56 percent of all components extracted while household gender composition with eigen-value of 1.17 contributed the least variance of 2.85 percent.

\subsubsection{Water storage}

The contribution of water storage as shown in Table 4 contributed the highest percentage of 10.56 percent to rural water supply. [24] and [25] also observed that water storage type contributes to water availability for domestic uses. It is noted that 86.5 percent of the respondents discovered the need to conserve water for their home use. Many homes found that one of the ways to avoid crisis associated with water availability for home use is to conserve water in their drums of varying sizes and types, which include jericans, clay pots and buckets of different sizes.

\subsubsection{Cost of water}

Table 4 showed that the influence of cost of water in the study area contributed 8.96 percent to the explanation of rural water supply. The influence of cost attached to water supply on domestic water use was also noted by [26] and [27]. Most households' access to underground water is encouraged because no cost is attached to it. Most homes claimed that they do not pay for water due to their poor level of income. However, where there is need for financial contribution to the maintenance of water facilities, people resorted to surface sources. People in Iwata (Ogo-Oluwa LGA) prefer alternative sources such as streams and rivers whenever there is power outage instead of contributing money for the purchase of gasoline to power the generator. A similar situation was found in Olorunkemi/ Olose (Egbeda LGA) where the vandalized solarpower borehole has been abandoned for other alternative sources for lack of willingness/ability to contribute for its repair and security. The observation here is similar to [28].

\subsubsection{Size of family}

The size of family contributed to the explanation of rural water use with a variance of 7.25 percent out of 62.47 percent contributed by the eleven components. The influence of household size on domestic water use was also observed by [29] and [30]. Even though, other variants come to play in household water use, the number of people in homes generally tells of the quantity of water that will be used for various domestic purposes. As indicated in Table 4, the daily water use of different ranges was dominated by home group of 6 to 10. It was generally discovered that the higher the number of inhabitants in a family, the higher the water used as also observed by [31].

\subsubsection{Water supply for bathing}

The contribution of water supply for bathing contributed 6.41 percent to rural water supply as shown in Table 4. [32] discovered that water use for showers and baths increased with household size and children and, that teenagers used more water for this purpose than adults. The influence of water used for bathing is probably explained by the closeness of water source and the availability of alternative sources, which encourage limitless use of water for bathing. The inhabitants in the rural areas of Oyo state attach importance to daily bath especially when water is abundant as in the raining season rather than rationing as observed in the northern part of Nigeria [33]. 


\subsubsection{Alternative sources}

The availability of alternative sources of water is also important in determining the rural household use of water having contributed 6.05 percent to the variance in domestic water use as revealed in Table 4. [34] noted in one of their study areas that the water from boreholes is widely and frequently used for drinking than that from other sources. Most rural communities investigated had several dug-out wells either provided by individual members of the community, politicians and even government apart from surface sources and abundant rainfall, which are readily available for home use.

\subsubsection{Location of water sources}

Most homes have hand-dug wells close to them, thus encouraging unrestricted use of water with a contribution on 4.72 percent as shown in Table 4 . The proximity of water source to the point of use avails the opportunity for possible misuse of water by the user. Inhabitants in village like Onipanu and Idi-Ayin (Surulere LGA) among others studied have underground sources constructed by either the government, philanthropists (mostly politicians) and other individuals, which make this source readily accessible. [35] and [36] noted from their different study areas that the location of water sources among other factors, contributed to domestic water uses.

\subsubsection{Reliability of the source}

This component contributed 4.51percent of variance to the explanation of rural water supply as in indicated in Table 4. The reliability of water source, also note by [37] is important as the presence of water source/s or its location may prove insignificant if either the quality is doubtful or the quantity is not dependable for adequate and prompt supply for home use. Some respondents in Kueke (Surulere LGA) and Dogo (Olorunsogo LGA) had claimed that they need to resort to another source in another location for drinking water because the one at their doorstep does not fit for drinking but for washing clothes.

\subsubsection{Access to water supply}

Table 4 revealed that the contribution of access to water supply is 3.98 percent of variance to the explanation of rural home water use. The contribution of this component explains that accessibility to potable water is still poor. However, the efforts of Oyo state government in ensuring access to water as observed by [11] could have probably contributed to this percentage. When there is unrestricted access to water, its usage for various purposes improves. [37] observed among other determinants, that poor access to water supply form the major factor that affect water supply in Ugbokolo community.

\subsubsection{Distance to the source of water}

This variant contributed 3.76 percent to the explanation of domestic water supply in the rural areas investigated as shown in Table 4 . The contribution of this component implies that the closer the water source, the higher the supply for home use as also observed by [37]. However, when water source is far it impedes unobstructed usage but rather encourages rationing. The study area was observed to have diverse sources both surface and subsurface apart from rainfall, which could be exploited for home use.

\subsubsection{Age of the respondent}

Table 4 showed that the age of the respondent also contributed 3.41 percent of variance to rural water supply in the study area. Dominant respondent here were mostly women by virtue of their noted responsibility in water provision. It is expected that less water may be required for home use where the woman is old or young with less number of people in the family unlike where the woman is middle aged with many children and other extended family members under her roof. However, [38] had a contrary observation on this parameter where it was discovered that age, among other factors had insignificant statistical contribution in predicting the water source decision of households. However, [3] discovered that domestic water consumption in the rural area of their study is highly affected the characteristics of heads of households among others which substantiate the finding in this study.

\subsubsection{Gender composition}

Gender composition contributed 2.85 percent to domestic water supply in the study area as noted in Table 4. This implies that the number of males and females determine domestic water use in the rural areas. It is expected that homes with higher proportion of females have tendency to use more water than homes dominated with males the reason is that women have been found to use more water for sanitation and hygienic purposes than their male counterparts [39]. 


\subsection{Relationship between Water Demand and Water Use Components in the Study Area}

Multiple regression analysis was carried out to examine the relationships between household water and water use determinants in the State as a whole. The State's collective percentage explanation of rural domestic water demand in Oyo State is $R^{2}=35$ percent; $S . E=115.32$. The implication of these findings is that the problem of rural water supply in Oyo State should not be lumped together but should be tackled separately, one local government area from the other.

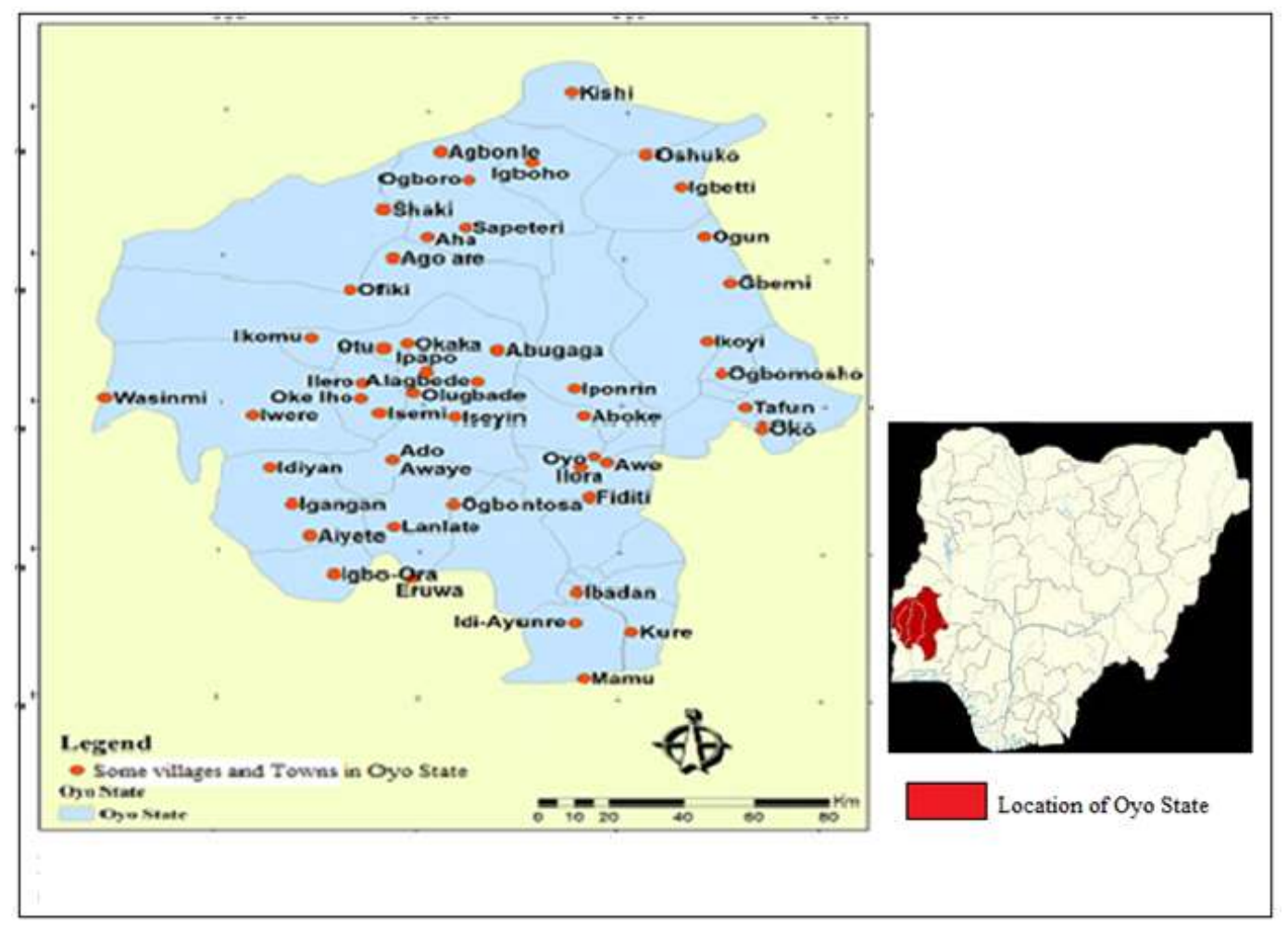

Fig. 1. Map of Oyo State showing some of the rural communities investigated (Inset: Map of Nigeria showing the location of Oyo State)

(Source: Google images)

Table 1. Average daily per capita water use (Ipd) in the rural areas of Oyo State

\begin{tabular}{llllll}
\hline S/N & $\begin{array}{l}\text { Name of local } \\
\text { government }\end{array}$ & $\begin{array}{l}\text { Per capita water } \\
\text { use }(\mathbf{l p d})\end{array}$ & $\mathbf{S} / \mathbf{N}$ & $\begin{array}{l}\text { Name of Local } \\
\text { Government }\end{array}$ & $\begin{array}{l}\text { Per capita water } \\
\text { use (lpd) }\end{array}$ \\
\hline 1. & Afijio & 29.5 & 13. & Kajola & 19.4 \\
2. & Akinyele & 24.4 & 14. & Lagelu & 24.0 \\
3. & Atisbo & 17.6 & 15. & Ogo-Oluwa & 25.5 \\
4. & Egbeda & 17.1 & 16. & Olorunsogo & 22.8 \\
5. & Ibarapa Central & 26.9 & 17. & Oluyole & 15.8 \\
6. & Ibarapa East & 20.9 & 18. & Ona-Ara & 23.9 \\
7. & Ibarapa North & 28.3 & 19. & Oorelope & 15.5 \\
8. & Ido & 24.9 & 20. & Oriire & 25.6 \\
9. & Irepo & 31.2 & 21 & Oyo East & 31.7 \\
10. & Iseyin & 30.2 & 22. & Oyo West & 23.5 \\
11. & Itesiwaju & 17.4 & 23. & Shaki East & 18.7 \\
12. & Iwajowa & 16.8 & 24. & Shaki West & 15.0 \\
& & & 25. & Surulere & 26.2 \\
\hline
\end{tabular}




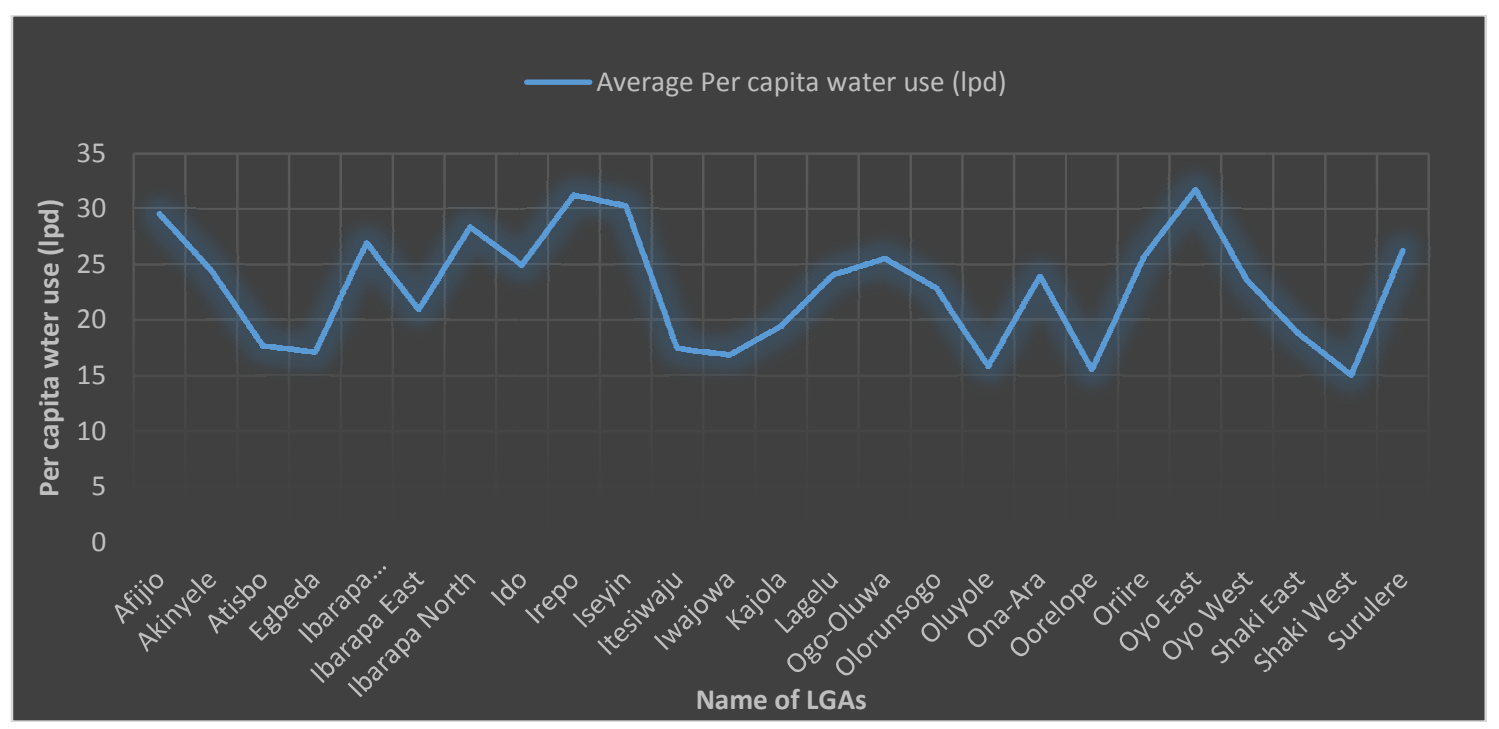

Fig. 2. Per capita water use (Ipd) in the rural areas of Oyo State Source: Authors' fieldwork (2012)

Table 2. Uses of water by percentage of households in the study area

\begin{tabular}{llll}
\hline S/N & Use of water & Total respondents & Percentage \\
\hline 1. & Cooking & 1231 & 100 percent \\
2. & Drinking & 1231 & 100 percent \\
3. & Bathing & 1231 & 100 percent \\
4. & Cloth Washing & 1231 & 100 percent \\
5. & Dish Washing & 1231 & 100 percent \\
6. & Toilet & 32 & 2.60 percent \\
7. & Car Washing & 243 & 19.68 percent \\
8. & Others & 146 & 11.86 percent \\
\hline
\end{tabular}

Table 3. KMO and Bartlett's test of the dataset

\begin{tabular}{ll}
\hline Kaiser-Meyer-Olkin Measure of sampling adequacy & .678 \\
Bartlett's Test of Sphericity (Approximate Chi-square) & $2.509 \mathrm{E} 3$ \\
Df & 55 \\
Significance & .000 \\
\hline
\end{tabular}

Table 4. Water use determinants and their respective contribution to the explanation of rural water demand

\begin{tabular}{llllll}
\hline S/N & $\begin{array}{l}\text { Water use component } \\
\text { extracted }\end{array}$ & $\begin{array}{l}\text { Component } \\
\text { loading }\end{array}$ & Eigen-value & $\begin{array}{l}\text { Percent of } \\
\text { variance } \\
\text { explained }\end{array}$ & $\begin{array}{l}\text { Cumulative } \\
\text { variance } \\
\text { explained }\end{array}$ \\
\hline 1. & Water Storage type & 0.871 & 4.33 & 10.56 & 10.56 \\
2. & Cost of water & 0.842 & 3.67 & 8.96 & 19.52 \\
3. & Size of family & 0.907 & 2.97 & 7.25 & 26.77 \\
4. & Water supply for bathing & 0.803 & 2.63 & 6.41 & 33.18 \\
5. & Alternative sources & 0.720 & 2.48 & 6.05 & 39.23 \\
6. & Location of water source & 0.729 & 1.94 & 4.72 & 43.95 \\
7. & Reliability of the source & 0.826 & 1.85 & 4.51 & 48.46 \\
8. & Access to water supply & 0.640 & 1.63 & 3.98 & 52.45 \\
9. & Distance to the source & 0.575 & 1.54 & 3.76 & 56.21 \\
10. & Age of the house head & 0.780 & 1.40 & 3.41 & 59.62 \\
11. & Gender composition & 0.643 & 1.17 & 2.85 & 62.47 \\
\hline
\end{tabular}




\section{CONCLUSION AND RECOMMENDA- TION}

An investigation into the pattern of water utilization in homes is desirable if result-oriented water management and planning will be realized. The findings in this work have revealed that domestic water use in the rural areas of Oyo State is absolutely domestic. Water consumption is mainly required for drinking, washing, cleaning, bathing and cooking among others. It was further revealed that water use for sanitary and car wash purposes were negligible in the study area. The implication of these findings is that the rural economy in the study area is poor and indicating an agrarian economy. It also shows that the study area is poverty-ridden who do not have access to better means of livelihood such as better sanitation, poor environment, subsistence farming, poor means of transportation, malnutrition, labor-intensive farming system, rainfed agriculture among others. Thus, there is need for the intervention of relevant agencies of Oyo State government and other stakeholders in the provision of infrastructural facilities and enhancement of the economy of rural dwellers especially through mechanized farming. The results of factor and multiple regression analyses have shown that various factors determine domestic water consumption in the local government areas investigated which needs to be studied for better planning and management of this resource. In addition, overall State's $\mathrm{R}^{2}$ value of 35.0 is an indication that resolution to water management and planning across the 25 LGAs cannot be lumped together but rather be treated individually. Further research is suggested on water demand modeling in the study area for the possibility of predicting water utilization.

\section{COMPETING INTERESTS}

Authors have declared that no competing interests exist.

\section{REFERENCES}

1. United Nation Initiative on Children Education Fund, The one million water and sanitation (WASH) initiative-baseline survey report on Zimbabwe, Nairobi: NE Consult Lda; 2009.

2. Arouna A, Dabbert S. Determinants of domestic water use by rural households without access to private improved water sources in Benin. A seemingly unrelated Tobit approach. Water Resources Management. 2009;9504-4.

3. Fan L, Liu G, Wang F, Geissen V, Ritsema CJ. Factors affecting domestic water consumption in rural households upon access to improved water supply: Insights from the Wei River Basin, China. PLoS ONE. 2013;8(8):e71977.

DOI: 10.1371/journal.pone.007197

4. Zhang C, Dong L, Liu Y, Qiao H. Analysis on impact factors of water utilization structure in Tiajin, China. Sustainability, 2016;8:241.

DOI: $10.3390 /$ su8030241

5. Keshavarzi AR, Sharifzadeh M, Haghighi Kamgar AA, Amin S, Keshtkar Sh., Bamdad A. Rural domestic water consumption behavior: A case study in Ramjerd area, Fars province, I.R. Iran. Water Research. 2006;40:1173-1178.

6. Ogunbode TO, Ifabiyi IP. Determinants of domestic water demand in a growing urban centre in Osun State, Nigeria. African J. Environment and Technology. 2014;8(4): 247-255.

7. World Bank. World development indicators, the World Bank; 2012.

Available:http//data.worldbank.org/sites/def ault/files/wdi-2012.ebook.pdf

(Accessed 20.02.2013)

8. Ogunbode TO, Akintunde EA, Akinola OT. Assessment of underground water quality and pollution sources apportionment in a growing urban centre in Osun State, south western, Nigeria. European Journal of Geography. 2016;7(3):70-84.

9. Thomas T. Definition of water security (Personal communication) Trivandram Planning meeting; 1998.

10. Ogunbode TO. Domestic water Utilisation and management in selected rural areas of Oyo State, Nigeria. An Unpublished PhD. Thesis, Department of Geography, University of Ilorin, Ilorin, Nigeria. 2015; 287.

11. Gbadegesin N, Olorunfemi F. Assessment of rural water supply management in selected rural areas of Oyo State, Nigeria. African Technology Policy Studies Network (ATPS) Working Paper Series No. 49; 2007.

12. Ayoade JO. Tropical hydrology and water resources. Macmillan, Nigeria; 2007.

13. Yusuf RO, Ukoje JA. Recent observations in rural geographic research in Nigeria. Research Journal of Environmental and Earth Sciences. 2010;2(2):76-81. 
14. Wolfe R, Fischer V. Methods for rural/nonrural determination for federal subsistence management in Alaska. Report to the US fish and wildlife Senice, Alaska region by Wolfe, J.R and associates and the Institute of Social and Economic Research, University of Alaska; 2003.

15. Olawepo RA. Determining rural farmers' income: A rural Nigeria experience. Journal of African Studies and Development Studies. 2010;2(2):99-108.

16. Zhang HH, Brown DF. Understanding urban residential water use in Beijing and Tianjin, China. Habitat International. 2005;29:469-491.

17. United States Agency for International Development (USAID). Nigeria: Water and sanitation Profile www.usaid.Gov; 2010.

18. Ishaku HT, Rafee Majid M, Ajayi AP, Haruna A. Water supply dilemma in Nigerian rural communities: Looking towards the city for an answer. Journal of Water Resources and Protection. 2011;3: 598-606.

19. Ali JO. Adequate water supply as a rural poverty reduction strategy in developing countries: A review of the literature. Journal of Environmental Research and Management. 2012;3(8):132-136.

20. Onwuemele A, Ekuase IO. An analysis of a typical rural economy in Nigeria and its connection to climate change adaptation. Journal of Environmental Management \& Safety. 2011;2(2):111-121.

21. Egbe EJ. Rural and community development in Nigeria: An assessment. Arabian Journal of Business and Management Review (Nigerian Chapter). 2014;2(2):17-30.

22. Ayoade JO, Oyebande L. Water resources, In J.S. Oguntoyinbo (ed.); A geography of Nigerian Development. Ibadan: Heinemann Educational Books Ltd. 1978; 180-235.

23. Adedayo A, Ifabiyi IP. The distribution of water and the role of public agencies in Kwara State. Journal of Social and Management Studies. 1999;6:97-112.

24. Issaka Z, Mansah E, Agyare WA, Ofori E. Appropriate rainwater harvesting storage capacity for households: A case study of central Gonja District. World Rural Observation. 2012;4(4):57-63.

25. Danquah L, Awuah E, Agyemang S, Mensah CM. Investigating the predictors of domestic water consumption in urban households with children under-five years:
A panel study in the Atwima Nwabiagya District, Ghana. Journal of Sustainable Development. 2015;8(8):1-17.

26. Dube E, van der Zaag P. Analysing water use patterns for water demand management: The case of the city of Masvingo, Zimbabwe. $3^{\text {rd }}$ WARFSA/Water Net Symposium, Arusha, 30-31 October; 2002.

27. Romano G, Salvati N, Guerrini A. Estimating the determinants of residential water demand in Italy. Water. 2014;6: 2929-2945.

DOI: 10.3390/w6102929

28. Jansen A, Schulz E. Water emand and urban poor: A study of the factors influencing water consumption among households in Capetown, South Africa. Working Paper series in Economics and Management. No 02/06. 2006;26.

29. Grafton $R Q$, Ward MB, To H, Kompas $T$. Determinants of residential water consumption: Evidence and analysis from a 10-country household survey. Water Resources Research. 2011;47: W08537.

DOI: 10.1029/2010WR009685

30. Rauf S, Bakhsh K, Hassan S, Nadeem AM, Kamran MA. Determinants of a household's choice of drinking water source in Punjab, Pakistan. Pol. Journal of Environmental Studies. 2015;24(6):27512754.

DOI: $10.15244 /$ pjoes/59256

31. Almottiri FA, Wegian FM. The influence of water and sewage networks on residential water consumption. International Journal of Water resources and Environmental Engineering. 2010;2(4):103-106.

32. American Water Works Association. The case for maintaining a disinfectant residual. American Water Works Association Journal. 1999;1(1):86-94.

33. Nyong AO, Kanaroglou PS. Domestic water use in rural semi-arid Africa: A case study of Katarko village in North Eastern Nigeria. Human Ecology. 1999;27(4):537555.

34. Howard G, Tenton J, Luyima P, Odongo R. Water usage patterns in low-income urbancommunities in Uganda: Implications for water supply surveillance. International Journal of Environmental Research. 2002; 12:63-73.

35. International Food Policy Research Institute Improved water supply in the Ghanaian Volta Basin: Who uses it and 
who participates in community decision making? Environment and Production Technology Discussion Paper, 129. 2005; 61.

36. Muweesi C, Lule R. Factors influencing rural households' choice of domestic water sources in Uganda: A case study of Kibibi Sub County- Mpigi District. A Research Paper submitted to the School of Postgraduate Studies of Makerere University, November; 2011.

37. Aper JA. The determining factors of rural water supply pattern in Ugbokolo Community, Benue State, Nigeria. Journal of Sustainable Development. 2011;4(2): 225-233

38. Dagnew DC. Factor determining residential water demand in North Western Ethiopia, The case of Merawi. A project paper presented to the faculty of the postgraduate school of Cornell University. 2012;90.

39. Aureli A, Brelet C. Women and water: An ethical issue. World Commission on the ethics of scientific knowledge and technology. Series of Water and Ethics, Essay 4 UNESCO, France; 2004. 


\section{APPENDIX I}

\section{The 25 Local Government Areas and the Selected Rural Communities}

\begin{tabular}{|c|c|c|}
\hline $\mathbf{S} / \mathbf{N}$ & Name of LGA & Name of five rural communities selected \\
\hline 1. & Afijio & Jobele, Farm Settlement, Kiyeseni, Aje and Onifa \\
\hline 2. & Akinyele & Motunde, Akinyele, Iroko, Onidundu and Akinkunmi \\
\hline 3. & Atisbo & KoonaOwo, Onikeke, Agunrege, Baasi and Tede \\
\hline 4. & Egbeda & Adeleye, AtaariAjibola, Olose, Badeku and Erunmu \\
\hline 5. & Ibarapa Central & Aba Alabi, BaaleAgbe, Balogun, Olurin and Fedegbo \\
\hline 6. & Ibarapa East & Temidire, Maya, Okolo, Lanlate, Olonde \\
\hline 7. & Ibarapa North & Ayete, Igangan, Tapa, Obape and Ofiki \\
\hline 8. & Ido & Onigbinde, Bakatari, Araromi-Idowu, Oloka and Ilaju \\
\hline 9. & Irepo & Adagbangba, Budo-Baba-Timo, Geesi, Tegese and Igbo-Elemi \\
\hline 10. & Iseyin & Apata, Idi-lya, Idi-Oori, Apenpe and Osoogun \\
\hline 11. & Itesiwaju & Baba-Ode, Komu, Igbo-ljaye, Oke-Amu and Alaga \\
\hline 12. & Iwajowa & Ilero, Gbedu, Ayetoro, Ilaji and Ilua \\
\hline 13. & Kajola & Ayetokowosi, Idi-Ayin, Adekunle, Elewure and Igbo-Olosan \\
\hline 14. & Lagelu & Ejioku, Ile-Igbon, Oree, Lagun and Aba-Aafa \\
\hline 15. & Ogo-Oluwa & Iwata, Pontela, Ladanu, Opete and Lagbedu \\
\hline 16. & Olorunsogo & Keso, Apata-Laje, Ojo-Aaro, Dogo and Olose \\
\hline 17. & Oluyole & Olojuoro, Olubi, OjuOro, Adebayo and Asipa \\
\hline 18. & Ona-Ara & Gbada, Araro, Ajia, Gbedu and Oduku \\
\hline 19. & Oorelope & Sooro, Budo-Ezekiel, Odo-Ogun, Alaguntan and Opo \\
\hline 20. & Oriire & Saamo, Olorunda, Aitete, Budo-Ode and Obamo \\
\hline 21. & Oyo East & ljawaya, Aba-Loya, Dada, Alaidan and Tokun-Idode \\
\hline 22. & Oyo West & Eleja, lya-Ibeji, Alagbon, Fasola and Lakonu \\
\hline 23. & Shaki East & Araromi, Ogbooro, Sepeteri, Ago-Amodu and Oje-Owode \\
\hline 24. & Shaki West & Oke-Imua, Simi-Akorede, Sanni-Sala, Ajelaawa and Wasangari \\
\hline 25. & Surulere & Idi-Ayin, Kueke, Eleeru, Igbo-lle and Onipanu \\
\hline
\end{tabular}




\section{APPENDIX II}

\section{Rotated component matrix of rural water demand variables}

\begin{tabular}{|c|c|c|c|c|c|c|c|c|c|c|c|}
\hline \multirow[t]{2}{*}{ Water demand variables } & \multicolumn{11}{|c|}{ Component } \\
\hline & 1 & 2 & 3 & 4 & 5 & 6 & 7 & 8 & 9 & 10 & 11 \\
\hline 1. Level of education & .036 & -.149 & .024 & -.092 & -.446 & .033 & .033 & -.020 & .121 & -.547 & -.068 \\
\hline 2. Sex & -.010 & .125 & -.014 & .011 & -.019 & -.080 & -.135 & .082 & -.102 & .322 & .643 \\
\hline 3. Age & -.053 & .008 & -.007 & .022 & -.071 & .079 & .046 & -.026 & .130 & .780 & .007 \\
\hline 4. Household Size & .002 & -.031 & .907 & .063 & -.032 & .007 & -.025 & -.016 & .039 & .019 & .012 \\
\hline 5. No of females & -.013 & .084 & .844 & -.020 & -.021 & .035 & -.020 & -.057 & .142 & .044 & -.057 \\
\hline 6. No of males & .034 & -.010 & .857 & .053 & .026 & .024 & .010 & -.049 & .028 & .029 & .020 \\
\hline 7. No of children in school & -.060 & -.057 & .752 & -.006 & -.032 & -.044 & .025 & .128 & -.064 & -.100 & -.014 \\
\hline $\begin{array}{l}\text { 8. House head Monthly } \\
\text { income }\end{array}$ & .074 & -.209 & .009 & -.081 & -.328 & .109 & .185 & .579 & -.178 & .146 & -.022 \\
\hline 9. Distance to water source & -.021 & -.013 & .133 & -.121 & -.112 & -.060 & -.194 & .013 & .575 & .056 & -.090 \\
\hline 10. Water supply for drinking & -.081 & .017 & .003 & .573 & .021 & .273 & -.011 & .130 & -.017 & -.090 & -.229 \\
\hline 11. Water supply for cooking & -.129 & .125 & .022 & .754 & .090 & .240 & .018 & .115 & -.054 & .024 & -.095 \\
\hline 12. Water supply for bathing & -.065 & .104 & .070 & .803 & .027 & -.039 & .062 & .054 & -.064 & .044 & .044 \\
\hline $\begin{array}{l}\text { 13. Water supply for washing } \\
\text { clothes }\end{array}$ & -.044 & .044 & -.007 & .653 & .091 & -.083 & .026 & -.104 & .004 & -.044 & .188 \\
\hline $\begin{array}{l}\text { 14. Water supply for dish } \\
\text { washing }\end{array}$ & .044 & -.024 & .006 & .647 & -.013 & .003 & .003 & -.053 & -.018 & .102 & -.067 \\
\hline $\begin{array}{l}\text { 15. Water supply for toilet } \\
\text { cleaning }\end{array}$ & .088 & -.219 & -.010 & -.089 & .053 & .054 & .077 & -.048 & -.064 & -.169 & .451 \\
\hline 16. Other uses & -.040 & -.049 & .096 & -.036 & -.638 & -.127 & .162 & .127 & .074 & .089 & .127 \\
\hline 17. Name of water source & .674 & .249 & -.009 & -.065 & .088 & -.177 & -.399 & .156 & .079 & -.054 & .033 \\
\hline 18. Water source provider & .452 & -.160 & .015 & -.109 & -.321 & -.331 & .264 & .127 & .188 & .030 & .184 \\
\hline 19. Water source Location & -.113 & -.121 & .058 & .213 & .036 & .729 & .148 & -.069 & -.080 & .089 & -.055 \\
\hline $\begin{array}{l}\text { 20. Positive attitude to } \\
\text { conservation }\end{array}$ & -.848 & .206 & .018 & .094 & -.033 & -.008 & -.057 & -.040 & .061 & .042 & -.053 \\
\hline $\begin{array}{l}\text { 21. Negative attitude to } \\
\text { conservation }\end{array}$ & -.874 & .199 & .014 & .073 & -.105 & -.041 & -.070 & -.043 & .041 & .056 & -.008 \\
\hline 22. Water storage type & .891 & .002 & -.024 & -.048 & .082 & -.058 & .017 & .155 & .020 & .014 & -.052 \\
\hline
\end{tabular}


Ogunbode and Ifabiyi; ARJASS, 3(3): 1-13, 2017; Article no.ARJASS.34096

\begin{tabular}{|c|c|c|c|c|c|c|c|c|c|c|c|}
\hline $\begin{array}{l}\text { 23. Frequency of water } \\
\text { availability }\end{array}$ & .329 & -.604 & .020 & -.064 & -.040 & .208 & .114 & -.233 & -.221 & -.083 & .149 \\
\hline 24. Time spent in fetching & .017 & .384 & .059 & .093 & -.332 & .011 & .064 & .168 & .480 & .098 & -.159 \\
\hline 25. Decision on payment & -.144 & .534 & -.102 & -.066 & .395 & -.043 & -.108 & .156 & .073 & .047 & -.112 \\
\hline 26. Amount being paid & .144 & -.842 & -.012 & -.090 & .084 & .037 & -.079 & -.016 & -.107 & -.039 & .080 \\
\hline $\begin{array}{l}\text { 27. Availability of Pipe-borne } \\
\text { water }\end{array}$ & .074 & -.544 & -.013 & -.049 & -.090 & .403 & .019 & -.283 & -.025 & .016 & -.029 \\
\hline $\begin{array}{l}\text { 28. Household preference for } \\
\text { a source }\end{array}$ & .464 & .349 & -.002 & -.001 & -.005 & .565 & -.059 & -.092 & .141 & -.106 & .099 \\
\hline 29. Reason for the preference & .366 & .319 & .034 & -.021 & .100 & -.468 & -.094 & -.213 & .197 & -.150 & -.081 \\
\hline 30. Regularity of water supply & .227 & .073 & .042 & .083 & .037 & -.231 & -.122 & .640 & .163 & -.141 & -.025 \\
\hline 31. Irregularity of the supply & .515 & .119 & -.067 & .098 & .158 & .030 & -.002 & .585 & .116 & .023 & .102 \\
\hline 32. Reliability of the supply & .010 & .104 & -.003 & .049 & -.062 & .048 & .826 & .028 & .017 & .001 & -.060 \\
\hline 33. Unreliability of the source & -.007 & -.721 & -.001 & -.113 & .128 & -.064 & -.003 & .098 & .211 & .012 & -.068 \\
\hline $\begin{array}{l}\text { 34. Water availability in dry } \\
\text { season }\end{array}$ & .028 & .129 & -.033 & .075 & .484 & .078 & .641 & -.015 & -.157 & -.012 & .079 \\
\hline $\begin{array}{l}\text { 35. Dry season short supply of } \\
\text { water }\end{array}$ & .394 & .006 & .050 & .023 & .643 & -.107 & .087 & .050 & -.055 & .063 & .048 \\
\hline 36. Alternative source of water & .097 & -.054 & .046 & .132 & .720 & -.083 & .257 & .048 & -.040 & .089 & .088 \\
\hline 37. Category of fetchers & -.009 & -.293 & -.083 & -.115 & -.120 & .166 & .163 & .143 & .511 & -.301 & .333 \\
\hline 38. Age range of fetchers & .090 & .573 & -.077 & .031 & .194 & .050 & .171 & -.161 & -.157 & .031 & .035 \\
\hline 39. Daily fetchable quantity & .324 & .500 & .233 & .004 & .093 & .031 & .305 & -.183 & .021 & .108 & -.106 \\
\hline $\begin{array}{l}\text { 40. Respondents perception } \\
\text { on water supply }\end{array}$ & .373 & -.054 & .038 & -.051 & .121 & -.270 & .260 & -.091 & .478 & .186 & -.153 \\
\hline $\begin{array}{l}\text { 41. Respondents' view water } \\
\text { accessibility }\end{array}$ & .300 & .227 & .075 & -.134 & .110 & -.362 & .110 & .182 & -.234 & .222 & -.324 \\
\hline
\end{tabular}

Source: SPSS-generated

(c) 2017 Ogunbode and Ifabiyi; This is an Open Access article distributed under the terms of the Creative Commons Attribution License (http://creativecommons.org/licenses/by/4.0), which permits unrestricted use, distribution, and reproduction in any medium, provided the original work is properly cited.

Peer-review history:

The peer review history for this paper can be accessed here:

http://sciencedomain.org/review-history/19513 